\title{
Russia's Crony Capitalism. The Path from Market Economy to Kleptocracy
}

\author{
Anders Åslund \\ New Haven \& London: Yale University Press 2019 \\ 324 sidor. ISBN 9780300243093
}

Recenserad av Erik Andermo [MSc. i internationell ekonomi från Handelshögskolan i Stockholm, associerad medarbetare vid Ryssland- och Eurasienprogrammet på Utrikespolitiska institutet, erik.andermo@gmail.com]

Vi lever i en tid då Sovjetunionens upplösning så sakteliga förpassas från ett levande minne till ett historiskt faktum, men vi har fortfarande förmånen att ta del av vittnesmålen från dem som närvarade vid denna omvälvande händelse. Det är därför särskilt uppfriskande att Anders Åslund nu ånyo har satt pennan till bladet för att uppdatera oss om sitt perspektiv på den väg Ryssland har slagit in på under Putins tid vid makten. Få personer kan göra anspråk på att, som Åslund i egenskap av ekonomisk rådgivare i Moskva, ha bevittnat Sovjetunionens upplösning och de efterföljande marknadsorienterade reformerna inifrån systemet självt.

Åslunds prosa är inbjudande och lättläst, men samtidigt kompakt koncentrerad med information och referenser till ett omfattande urval av såväl primära och sekundära källor som till de personliga erfarenheterna. Boken blir därför en viktig historieskrivning över hela epoken från Sovjetunionens kollaps 1991 fram till idag. Den är full av referenser till personliga möten med många av bokens huvudpersoner, såsom Boris Jeltsin, Jegor Gajdar, Viktor Tjernomyrdin och Michail Chodorkovskij, för att bara nämna några. Den innehåller därför flera intressanta detaljer, såsom att Putin på 90-talet påstås ha haft ägarintressen i ett hotell i finska Åbo. Dessutom förekommer flitiga referenser till det arbete som har gjorts av grävande journalister, specialister och antikorruptionsaktivister, såsom Christopher Steele, Alexej Navalnyj, Boris Nemtsov och Panamaläckorna, som har blottlagt dolda förehavanden hos den ryska eliten. Även för en läsare som redan är bekant med mycket av berättelsen bidrar dessa detaljer tillsammans med bokens tydliga struktur till att skapa en helhetsbild som väver samman en lång rad mångfacetterade episoder och skeenden.

Åslund återkommer flera gånger till att det fanns signaler redan vid Putins första tid vid makten om hans långsiktiga ambitioner för Ryssland, men att det är först i efterhand som de blir tydliga. Följaktligen framstår Putins konsolidering av makten som mycket målmedveten. Han poängterar förvisso att Rysslands väg under 
2000-talet är resultatet av Putins aktiva val och att utvecklingen inte var förutbestämd, men läsaren får nästan intrycket att Putin redan vid makttillträdet hade en tydlig bild av vilket Ryssland han ville forma och att Ryssland 2020 är ett resultat av den visionen. Narrativet är övertygande eftersom Åslund så tydligt visar hur Putin systematiskt har byggt upp ett system av statskapitalism och nepotism, och som läsare kan det vara bra att påminna sig själv om att inte tolka Åslund teleologiskt. Snarare handlar det om att Åslund, som har skrivit om Ryssland och dess ekonomi sedan 80-talet, nu med "facit» $\mathrm{i}$ hand försöker sortera intrycken.

Mellan 1989 och 2013 publicerade Åslund flera böcker som analyserade Rysslands väg från sovjetisk kommunism till marknadsekonomi. Undertiteln till den föreliggande boken, The Path from Market Economy to Kleptocracy, antyder att Åslund delvis har omprövat sin syn på Rysslands utveckling i takt med att Putin har konsoliderat makten. Han skriver i bokens inledande sidor att "förändringarna har genomförts gradvis men med stor beslutsamhet, så som har varit karaktäristiskt för Putins politik. De har inte varit lättbegripliga eftersom Putin har agerat skickligt i det fördolda.»

Titlarna till två andra böcker som Åslund refererar avslöjar var han antagligen har fått en del av sin inspiration: Putin's Kleptocracy av Karen Dewisha (2014) och China's Crony Capitalism av Minxin Pei (2016). Med hänvisning till den sistnämnda konstaterar Åslund att likheterna mellan Rysslands och Kinas statskapitalistiska system är slående. Efter en grundlig redogörelse av hur Putins närstående systematiskt har överfört statliga tillgångar i privat ägo följer en lika detaljerad genomgång som försöker uppskatta storleken på de förmögenheter som har förts ut ur Ryssland. Åslunds slutsats är att 800 miljarder dollar är en rimlig bedömning, och att ungefär hälften av detta belopp är hänförligt till Putin och hans närstående.

Åslunds kritik av det han kallar Rysslands deinstitutionalisering är ett bärande tema boken igenom, och han syftar då särskilt på den underminerade äganderätten och de urholkade demokratiska institutionerna. Detta argument omfattar en implicit idé om att institutionerna i någon bemärkelse var fullbordade under de ideala första åren på 2000-talet. Här skulle narrativet ha kunnat nyanserats något med en grundligare diskussion om varför dessa på pappret »ideala» institutioner i praktiken inte blev särskilt långvariga. Åslund visar systematiskt hur Putins politik och opportunism har urholkat demokratin och äganderätterna, men ett perspektiv som inte framkommer lika tydligt handlar om att vardagen för många ryssar vid den tiden präglades av stor ekonomisk osäkerhet, korruption och en våg av terrordåd som sammantaget skapade en efterfrågan på en starkare stat. Åslunds vän och kollega, reformatorn Jegor Gajdar, har i sina böcker framhållit betydelsen av nostalgin efter Sovjetunionen som en betydande faktor i det ryska politiska landskapet under 2000-talets början, men detta perspektiv diskuteras inte i boken, trots att Putin presenteras som en skicklig och opportunistisk politiker.

Putin har byggt ett system som värnar makroekonomisk stabilitet men där äganderätten är svag och endast minimal tillväxt är möjlig. Väst måste enligt Åslund 
värna sitt militära försvar för att undvika att dras in i krig, men framför allt måste transparensen stärkas så att det blir svårare för den korrupta ryska eliten att tvätta sina förmögenheter i utlandet. På det inrikespolitiska planet är Åslunds slutsats att deinstitutionaliseringen i Ryssland har gått så långt att förutsättningar saknas för att byta ekonomisk modell, med mindre än att regimen först kollapsar. Han menar att regimens uthållighet är betydande men begränsad och att dess maktbas krymper. En risk finns för att Putin tar större risker än han kan hantera. Tidsandan påminner om stagnationen under Brezjnev, och svågerkapitalismen kommer sannolikt inte att bestå. När tiden är mogen bör Ryssland därför enligt Åslund ersätta den nuvarande eliten med demokratiskt valda representanter, avskaffa säkerhetstjänsten FSB och reformera domstolsväsendet. Västvärlden, särskilt EU, bör stå redo att engagera sig. Sammantaget utgör boken en utmärkt redogörelse för hur Ryssland har hamnat $\mathrm{i}$ den här situationen. 